International Journal of Advanced Studies in Humanities and Social Science (IJASHSS)

Available online at http://www.ijashss.com

Volume 8, Issue 2 (2019) pp. 168-177

Original Article

\title{
The Impact of Organizational Determinants on Export Performance
}

\section{Zaher Hatami ${ }^{1}$, Somayeh Naseramini Jelodarloo ${ }^{2}$, Ebadat EmamgholizadehTakle ${ }^{3}$, Eslam Nazari ${ }^{*}$, Afshar Hatami ${ }^{5}$}

${ }^{1}$ Department of Industrial Management, Bilesavar Branch, Islamic Azad University, Bilesavar, Iran

${ }^{2}$ Department of Business Management, Bilesavar Branch, Islamic Azad University, Bilesavar, Iran

${ }^{3}$ M.Sc. Of Marketing Management

${ }^{4}$ Department of Business Management, Bilesavar Branch, Islamic Azad University, Bilesavar, Iran,

${ }^{5}$ M.Sc. Of Geography and Urban Planning

*Corresponding Author E-mail: Nazari1362mba@yahoo.com

Received: 24 October 2018, Revised: 05 December 2018, Accepted: 20 December 2018

\begin{abstract}
The main objective of this study is to investigate the influence of organizational determinants on export performance exporters of Ardabil Province. The purpose of this research and applied research in terms of research method is descriptive analytical. The questionnaire used to collect data for this study has been after localization and to ensure high reliability of the questionnaires, they were distributed. The study population included all exporters of Ardebil that the number 226 has been issued and using a sample of 138 Morgan was issued. For the analysis of the data spss19 software in two parts of descriptive and inferential statistics was used. Pearson correlation coefficient and multiple regression results indicate that variables of export performance with firm size and, export experience and commitment export have positive and significant relationship with dependent variable of export performance and also the results of multivariate regression shows that the export commitment variable has the greatest impact on export performance.
\end{abstract}

Keywords: Export Performance, Export Promotion, Export Experience, Export. Commitment.

\section{Introduction}

Today, with the expansion of communications and the advent of globalization phenomenon, goods, information and technology exchanges have improved and developed more than before. Manufacturers and exporters have found better chance than in the past to compete in international markets and expand their activities. according to the possibility of more and better 
manufactured production supplement and the balance of payments in countries, high export and increasing of employment level in different grounds, enhancement of quality of productions and making the competition aspects (Karbasi and Akbari Javad, 2008).

The importance of export promotion doubles under the conditions which newadvent economy globalization phenomenon and commercial bounds losing of countries are extremely forming and in near future countries will hardly keep away themselves from this trend and become only an observer of the global changes in margin. Because of these facts, it is expected that Iran adjusts itself someway with global commerce promotion and prepares for competition and entering in international commerce scene and active and yielding partnership with world economy (Permeh et. al., 2009).

\section{Statement of the Problem}

Commerce promotion, globalization of products and services and internationalization of companies have been added to the importance of international commerce relationships all of the time. International commerce relationships encompass different dimensions which influences the effectiveness of companies in international market especially export market. According to the condition of complicated, frequent and continuously changeable market, getting the commercial information quickly is predominantly the companies' trend which are working in unknown international markets and export environments, and encounter more environmental unreality under the disturbed conditions. There are more possibilities that company's products will not be consistent with client's requirements and competitor's productions and, as a result, the effectiveness of company's performances decreases. Therefore, in a more disturbed export environment, exporters need a great deal of information as an implement that increases their acquaintance on varied export conditions (Doaei and Hosseini Tohat, 2010). In such an environment with increasing of globalization of trade markets, economical system relationship and international relationship of strategies have been important (Navarro et al., 2010). Export status in Iran does not have a shining history, as achieving to marketing services is not easy for successful export performance and exporters deal with export affairs not as professional but as traditional and temporal. In accordance with these issues and non-petroleum export promotion, commerce promotion organization of Iran plays a significant role in export service delivery (Farhangi and Lotfi, 2009). Export promotion has an effect of foreign currency incomes receiving; furthermore, it has also another positive effect. Country's industries could increase their production amount and thus they could profit from more productivity advantages and lower finished price (Hassanzadeh and Shaban Elahi, 2009). In all of twelve months of 2010, according to statistics obtained from Customs Administration, province's export rate in term of value had been up to 73 million dollars, which in comparison with statistics in the same period of past year shows 42 percent increasing, while the weight of export products of the province in this period was up to 127 thousand tones that these figures also in comparison with the weight of export products of last year shows 34 percent increasing (www.acommerce.ir) 
and this shows the notable role of Ardabil province in export promotion; therefore, one of the main and essential objects of this study is expanding and developing an ideal pattern in order to analyze the impact of organization factors on export performance of Ardabil province exporters and examining its impact with variables of firm size, export experience, and export commitment. This study's main issue is evaluating the relationship between organizational determinants and export performance of Ardabil province exporters.

\section{Importance and Necessity of Research}

Exports are vital implements for countries to reach their economic prosperity balance of payments, employment rate and life standard recovery; thus, some governments encourage more exports and following export promotion (Doaei and Hosseini Robat, 2010) in an analysis which is done about export promotion. According to this fact that Iran's population is about 1 percent of world population, if this country wants to profit from world commerce as much as population share size, with an easy computation, it is required to have something about 180 billion dollars export until 1400. Reaching to this figure will imply the overall promotion of effective factors over export promotion (Fathi and Azizi, 2007). Identifying the determined factors of export performance, country's export performance recovery is the most important factor in making balance between country's economy and global economy (Haghighi and et al., 2009). So, researches should conduct and analyze market and existing competitors about export performance.

\section{Research Objects}

This study's expected results can be used for export performance recovery and entrance approaches to export market for export companies. Commercial affairs ministry, mining ministry, customhouse and commercial office and also export companies would be the main users from this study's results.

Main objects of this study are evaluating the organization factor's impact on exporter's export performance.

This study's derivative object includes:

Measuring the amount of firm size impacts on exporter's export performance of Ardabil province.

Measuring the amount of firm experience impacts on exporter's export performance of Ardabil province.

Measuring the amount of export commitment impacts on exporter's export performance of Ardabil province.

\section{Research Questions}

This study's basic question is: Is there any relationship between organizational determinants and exporter's export performance of Ardabil province?

This study's derivative question includes: Is there any relationship between firm size and exporter's export performance of Ardabil province?

Is there any relationship between export experience and exporter's export performance of Ardabil province?

Is there any relationship between export commitment and exporter's export performance of Ardabil province?

\section{Theoretical Framework}

A study was conducted by Stoian and et al. (2010) with the title of "export portion performance under microscope: a review to Spanish companies" which has investigated firm size, export experience and commitment impact on export portion performance in terms of objective and abstractive properties. The results of this study implied that there isn't any

$170 \mid$ Page 
significant relationship between firm size and objective and abstractive properties of export performance and there is a significant relationship between firm experiment and export performance from the point of view of objective property, and export commitment has a positive impact on export performance. Based on the study conducted by Stoian et al. (2010), the organizational determinants consist of: dependent variable (export performance) and independent variable (firm size, export experience, export commitment).

Independent variables

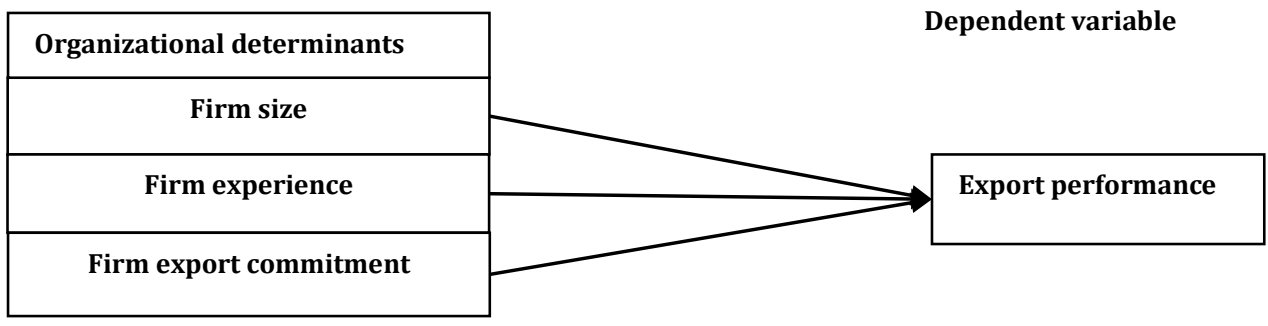

Figure (1) analytical model of research

\section{Export Performance}

Success amount of a company in export can be evaluated with its export performance. Kavosgil and Zou (1994) define export performance as the amount of reaching to objects, while the company exports production to external market. Researcher's disagreement on a unit conceptual and operational definition for export performance often has led to paradoxical and unrelated results in this case (Hosseini and Mir Jahanmard, 2011). In this study, export performance is measured by the indexes of export purchasing growth, export profitability, export density, access to expectations, competitor's evaluating in a five-interval scale known as Likert spectrum from very little to very much.

\section{Firm Size}

Organizational sources, economy to scale and existing risks understanding in international activities are three basic and main factors which led to firm size positively relate to export performance.
These advantages related to size, not only will facilitate the understanding of external market properties, also increase the effective responsibility and ability to external customer's requests and thus potentially they led to increasing of export performance level (Haghighi et al., 2009). In a study conducted by Haghighi, Firoziyan and Najafi Majd (2009) with the title of "Identifying the determinant factors of export performance in food industry", results of study implied that there is significant and positive relationship between the variables of external firm size and export performance. In this study, the firm size is measured by the index of firm employees' number with categories interval 19-49, 1-20, 50-99, 100-294, and up to 295.

\section{Export Experience}

Imperial knowledge about markets and external operations is a leading force in internationalization of companies. 
Increasing the export experiment will have some advantages for company such as (1) increasing the confidence from export activities, (2) better understanding of external market mechanism and finally (3) establishing a vast communication band with customers. Therefore, the programs effectively will follow designing and performing export markets. So, experienced exporters in contrast with other will operate better (Navarro et al., 2010). A study conducted by katiskis et al. (1995) with the title of "export performance dimensions in Europe hisoty" Shows the positive relationship between export experience and export performance.

In this study, export experience was measured with the number of years which company had export activities and with the number of countries which the company exported to them in category intervals of $1-5,6-70,11-15,16-20$, up to 21.

\section{Export Commitment}

Administration commitment to export activities has strong impact on manufacture's export success. To ensure the preserve and continue the export regular operations, understanding the foreign buyer's views and compliment of advanced marketing activities are essential that for establishing such a capacity, administration commitment to exports has much importance. Administration commitment reflects in activities such as discrete export unit, export planning and control, export marketing researches and regular inspections (or regulations) of export markets (Haghighi et al., 2009). Shoham and Albaum (1994) in an article entitled "the impact of marketing methods changing on export performance" have shown positive relationship between commitment and export performance. In this research, export commitment is measured by discrete export unit, entrance to external market and customer choice, regular inspections of export markets, using of export marketing researches, export planning and control at fiveinterval scale known as Likert spectrum from very little to very much degrees.

\section{Research Hypotheses}

\section{Basic hypotheses}

There is a significant relationship between organizational determinants and exporter's export performance of Ardabil province.

\section{Subsidiary hypotheses}

1. There is a significant relationship between firm size and exporter's export performance of Ardabil province.

2. There is a significant relationship between firm experience and exporter's export performance of Ardabil province.

3. There is a significant relationship between firm's export commitment and exporter's export performance of Ardabil province.

\section{Research Methodology}

This research in terms of purpose is an applied research and in terms of research method is a descriptive-analytical research from the kind of correlative study. Compiling data method is also surveying method. This study's statistical population consists of total number of Ardabil province exporters who have membered in database of exporters that in according to commercial office's information, they consist of 226 cases. Simple accidental sampling method has been applied for identifying the sample value. For identifying the sample value, Morgan table has been applied which shows 138 exporters. Out of 140 distributed- 
questionnaires, 138 questionnaires were collected and analyzed. To ensure the reliability of questionnaire, firstly, 30 questionnaires were distributed. It is identified that the mentioned questionnaire has high reliability (Alpha $=0.100$ ).

\section{Descriptive Statistics}

To examine this study's hypothesis, the SPSS software package in two parts of descriptive and inferential statistics has been applied. In descriptive statistics part, data have been analyzed by use of mean, standard deviation, and Maximum and minimum amount and also in inferential statistics part, data have been analyzed by Test of Pearson correlation coefficient and also multi-variant regression with Enter method.

Table1. Results of Descriptive Statistics Descriptive Statistics

\begin{tabular}{ccccccc}
\hline & $\mathbf{N}$ & Minimum & Maximum & Mean & Std. Deviation & Variance \\
\hline Firm size & 138 & 1,00 & 4,00 & 1,6739 &, 73656 &, 543 \\
Export experience & 138 & 1,00 & 4,00 & 2,0471 &, 84337 &, 711 \\
Export commitment & 138 & 1,00 & 4,20 & 2,6290 & 1,09719 & 1,204 \\
Export performance & 138 & 1,00 & 4,50 & 2,7536 & 1,12210 & 1,259 \\
Valid N (list wise) & 138 & & & & & \\
\hline
\end{tabular}

As Table (1) shows, maximum obtained score (value) for variable of firm size is 4 and its minimum value is 1 . Also, maximum obtained value for variable of export experience is 4 and its minimum value is 1 and for export commitment variable, maximum obtained value is 4.20 and minimum value is 1 the mean value and for export performance variable, maximum obtain value is 4.50 and minimum obtained value is 1 .

Standard deviation of variable of firm size and export experience and export commitment and export performance are $0.73653,0.84337,1.09717$, and 1.122100, respectively.

\section{Data Analysis}

Table 2. Result of testing hypotheses

\begin{tabular}{|c|c|c|c|c|}
\hline Hypotheses & $\mathbf{N}$ & $\begin{array}{c}\text { Pearson } \\
\text { Correlation }\end{array}$ & $\begin{array}{c}\text { p- } \\
\text { value }\end{array}$ & Result \\
\hline $\begin{array}{l}\text { Main. There is a Significant relationship between } \\
\text { organizational determinants and exporter's } \\
\text { export performance of Ardabil province }\end{array}$ & 135 & .882 & 000 & Confirmec \\
\hline H1. There is Significant relationship between & 135 & & & \\
\hline $\begin{array}{c}\text { Firm Size and exporter's export performance of } \\
\text { Ardabil province. }\end{array}$ & & .481 & .000 & Confirmed \\
\hline H2: There is Significant relationship between & 135 & & & \\
\hline $\begin{array}{l}\text { Export Experience of firm and exporter's export } \\
\text { performance of Ardabil province }\end{array}$ & & .735 & .000 & Confirmec \\
\hline H3. There is Significant relationship between & 135 & & & \\
\hline $\begin{array}{l}\text { Export Commitment of firm and exporter's } \\
\text { export performance of Ardabil province }\end{array}$ & & .93 & .000 & Confirmec \\
\hline
\end{tabular}




\section{Result of Main Hypothesis}

According to Table (2), it is observed that the amount is sig=/000 $</ 01$. Due to this result with 99 percent reliability, based on this table, it could be said that correlation amount between two variables of organizational determinants and exporter's export performance of Ardabil province is 88.2 percent which shows a direct relation between two variables. On the other hand, determinant coefficient between two variables of organizational determinants and export performance equals with 0.7779 which shows that independent variable can predict dependent variable with the amount of 77.79 percent.

\section{Result of First Hypothesis}

According to Table (2), it is observed that the amount is sig $=/ 000</ 01$. Due to this result with 99 percent reliability, based on this table, it could be said that correlation amount between two variables of firm province is 48.1 percent which shows a direct relation between two variables. On the other hand, determinant coefficient between two variables of firm size and export performance equals 0.2313 which shows that independent variable can predict dependent variable with the amount of 23.13 percent.

\section{Result of Second Hypothesis}

According to Table (2), it is observed that the amount is sig=000<01. Due to this result with 99 percent reliability, based on this table, it could be said that correlation amount between two variables of export experience and exporter's export performance of Ardabil province is 73.5 percent.

On the other hand, determinant coefficient between two variables of company experience and export performance is 0.5202 which shows that independent variable can predict dependent variable with the amount of $54.02 \%$.

\section{Result of Three Hypothesis}

There is a relationship between export commitment and export performance. According to Table (5), it is observed that the amount is sig $=.000<01$. Due to this result, with confidence of 88 percent, in accordance with the table, it could be stated that correlation density between two variables of export commitment and exporter's export performance of Ardabil province is 97.3 percent which shows a direct relationship between these two variables. On the other hand, determinant coefficient between two variable of export commitment and export performance equals 0.9467 which shows that independent variable can predict dependent variable, with the amount of 97.67 percent.

Table 3. Results of Multivariate Regression

\begin{tabular}{cccccc}
\multicolumn{8}{c}{ Model Summary $^{\mathbf{b}}$} \\
\hline Model & $\mathrm{R}$ & R Square & Adjusted R & Std. Error of & Durbin- \\
1 &, $976^{\mathrm{a}}$ &, 952 &, 951 & the Estimate & Watson \\
\hline
\end{tabular}

ANOVA $^{b}$

\begin{tabular}{cccccc}
\hline Model & Sum of Squares & df & Mean Square & F & Sig. \\
\hline Regression & 164,287 & 3 & 54,762 & 893,704 &, $000^{\mathrm{a}}$ \\
Residual & 8,211 & 134 &, 061 & & \\
Total & 172,498 & 137 & & & \\
\hline
\end{tabular}




\begin{tabular}{|c|c|c|c|c|c|}
\hline \multirow[b]{2}{*}{ Model } & \multicolumn{2}{|c|}{ Unstandardized Coefficients } & \multirow{2}{*}{$\begin{array}{c}\text { Standardized } \\
\text { Coefficients }\end{array}$} & \multirow[b]{2}{*}{$\mathrm{t}$} & \multirow[b]{2}{*}{ Sig. } \\
\hline & $\mathrm{B}$ & Std. Error & & & \\
\hline (Constant) & ,186 &, 062 & & 3,004 & 003 \\
\hline firm size &,- 141 & ,035 &,- 092 & $-3,998$ & ,000 \\
\hline $\begin{array}{c}\text { Export } \\
\text { Experience }\end{array}$ & ,091 &, 038 &, 068 & 2,398 & ,018 \\
\hline $\begin{array}{c}\text { export } \\
\text { commitment }\end{array}$ & ,995 & 030 & ,973 & 33,517 & 000 \\
\hline
\end{tabular}

In Table (6), results obtained from ANOVA test is shown. The results obtained from ANOVA test shows the reification of research hypothesis, because the amount of SIG in this test is 0.000 which is lower than the considered Alpha, namely it is $0.05 \%$.

In above table, the results obtained from Watson Durbin are shown. the gained statistic of Durbin-Watson test for model equals 1.568 and since the amount of Durbin-Watson test statistic (1.568) is laced in 1.5 and 2.5 intervals, the hypothesis "the lack of correlation between the errors" cannot be rejected and we can use from regression analysis in the continued, the results of the multivariate regression with Enter method are presented that data have been analyzed by use of this considered test. Results show that all of hypotheses came true. The gained sig for firm size variable is 0.000 which is lower than considered, it could be said that independent variable of firm size impacts on exporter's export performance of Ardabil province, Namely 1 percent change in 23.13 percent of company variable. One percent recovery on independent variable can recover the export performance with the amount of 23.13 percent, and it obvious that export experience variable in accordance with gained sig impacts on exporter's export performance and 1 percent change on export performance with the amount of
54.02 percent. Also, export commitment variable in accordance with gained sig which equals 0.000 , is lower than the considered Alpha with 0.05, thus with 95 percent confidence, it can be said that export commitment variable influences export performance. Namely 1 percent change on firm size variable can explain dependent variable with amount of 23.13. One percent recovery in independent variable can recover the export performance with amount of 23.13 percent. And it is obvious that export experience variable in accordance with obtained sig influences on export amount of exporters and one percent change in export performance of exports with the amount of 54.02. And also in according with obtained sig which equals 0.000 that is lower than considerable Alpha namely 0.5 . So with 95 percent confidence, it can be said that export commitment variable influences on export performance of exporters.

Finally, one percent change on export commitment variable can change the export performance of exporters of Ardabil province with the amount of 94.67. Since gained sig is bigger than 0.05 for constant amount and also for 3 variables, therefore, the assumption of regression coefficient and constant amount with the amount of zero is rejected and there is no necessity for exiting them from regression equation. So the regression equation is as 
following: standardized coefficients column (Beta) shows that the export commitment has the most impact on per one unite change in this variable, 0.973 change in export performance variable occurs.

\section{Conclusion and Recommendations}

Any economy empowerments, such as establishments and countries and regional unions and organization as minor economic actives try to gain more shares from existing advantages, facilitates and opportunities in the global business arena. Companies have profited from different approaches for entering in world market that one of them is export promotion approach. Since the export has required applying minimal resources, it has the lowest risk and also has the lowest organizational commitment, so export is the simplest way to entering and penetrating external markets. In this direction for export promotion, the effective factors on export should be identified and used in their decisions. In this study, we investigated the impact of organizational determinants on exporter's export performance.

Results obtained from this study and test of hypotheses are identified as following: The results gained from Pearson's correlation coefficient test showed that there is a positive and significant relationship between two variables of firm size and export performance and correlation coefficient had obtained 48.1 between two variables. on the other hand, The coefficient of determination between two variable equals 0.2313 and this shows that independent variable of firm size can predict exporter's export performance of Ardabil province with the amount of 23.13.

Meanwhile, the results obtained from the test of second hypothesis showed that there is a positive and significant relationship between two variables of export experience and export performance.

And correlation coefficient amount for these two variables equals 73.5. So, it can be said that independent variable of export experience can predict dependent variable of export performance with the amount of 54.02 and finally third hypothesis of study is accepted with 99 percent confidence, namely there is a positive and significant relationship between export commitment and export performance and this relationship is gained by case of Pearson's correlation coefficient test which equals 93.3 percent. Therefore, export commitment can recover export performance with the amount of 49.67 percent. And regression coefficient shows that firm size and export performance have inverse relationship with each other and obtained results from basic hypothesis test identifies that organizational determinants have a positive and significant relationship with export performance. The results obtained from this study verify the results gained from the researches of Katskis et al. (1994), Shoham and Alboum (1994). Therefore, in accordance with the results obtained from study, test of hypothesis, the following recommendation can be raised:

1- Formulating export marketing program will be done by use of guidelines of destination market importer and local distributor.

2. Regular reviews from export market will be done due to collecting worthy data and establishing close relation with key members of distribution band.

3. Participating in international exhibition can be effective in increasing exports.

4. International experience in export issue helps companies to identify international opportunities and avoid from threats. In 
accordance with significant impact of export experience on export performance, it is recommended to exporters to increase export range to different countries.

\section{References}

Doaei, H; Hosseini Robat, S.M. (2010). Market -oriented foreign trade, international trade relations and export performance) Case Study: Export companies in Mashhad, Iranian Journal of Modiriat Bazargani,Vol2,No6,pp 61-82

Farhangi, A.A; Ltfi, A. (2009). Journal of Management, Vol 1, no 2, pp 119-134

Fathi, S; Azizi, SH. (2007)._The effect of ebusiness export development: identifying priorities for the country's industrial sector. Journal of Management, no 45, pp 179 -220

Haghighi, $\quad$ M; Fyrvzyan, Mahmoud; Muhammad Najafi, S. (2009). Identifying determinants Mlkrdsadraty food industry. Journal of Management, Vol 1, no 1, pp 3 -20

Hassan zade, A; Elahi, Sh. (2009).The Role of e-banking in facilitating exports. Journal of Business Research, No. 47, Summer 2009, 265-235

Hoseyni, y; mirjahanmard, s .j. (2011).The function of exporting firms: identification of competitive advantages, implementation of marketing tactics and export experience on export performance. Journal of Marketing Research.new. First year.first issue. Spring.
Parme, Z; hoseyni, M.A; nabizade, Ah; mohebi, H. (2009).The capacity of saffron Iran export target markets. Journal of Business Research. No. 51. Summer. pp. 59-95.

Karbasi, A.R; akbarzade, J. (2008).Iran saffron export demand estimate simultaneous equations system. Agricultural Economics and Development, Vol 16, no 62, pp 33 -53

Katsikeas Constantine S., (1995)," Determinants of export performance in a European context", European Journal of Marketing, Vol. 30 No. 6, 1996, pp. 6-35.

Navarro A., Losada F., Ruzo E., Diez Jose A. (2010)," Implications of perceived competitive advantages, adaptation of marketing tactics and export commitment on export performance', Journal of World Business 45 : 49-58

Shoham A., baum G. (1994)," The Effects of Transfer of Marketing Methods on Export Performance: an Empirical Examination", International Business Review Vol. 3, No. 3, pp. 219-241.

Stoian M.C., Rialp A., Rialp J. (2010)," Export performance under the microscope: A glance through Spanish lenses", International Business Review xxx (2010) xxx-xxx.

www.commerce.ir

Zavar, P; Hoseyni, M.A; mohebi, H.R. (2009). Capacities of export and target markets Iran saffron .Journal of Management, no 51, pp 59 $-95$

How to cite this article: Zaher Hatami, Somayeh Naseramini Jelodarloo, Ebadat EmamgholizadehTakle, Eslam Nazari, Afshar Hatami, The Impact of Organizational Determinants on Export Performance. International Journal of Advanced Studies in Humanities and Social Science, 2019, 8(2), 168-177. http://www.ijashssjournal.com/article 84355.html 